Ann Nutr Metab. 1989;33:I-IV

\title{
Contents, Vol. 33, 1989
}

\section{Nutrition \& Metabolism}

European Journal of Nutrition, Metabolic Diseases and Dietetics Journal européen de nutrition, des maladies métaboliques et de diététique Europäische Zeitschrift für Emährungswissenschaft, Stoffwechselstörungen und Diätetik

Official Journal of the Federation of European Nutrition Societies Annals of Nutrition and Metabolism (formerly 'Annales de la Nutrition et de ГAlimentation' and 'Nutrition and Metabolism') is recognised by the 'Federation of European Nutrition Societies' (FENS) as its official journal Founded 1959 as 'Nutritio et Dieta by E. Azerad, H. Kapp and J. Trémolières Former Main Editor: A. Wretlind (1961-1969)

Continued as 'Nutrition and Metabolism' (1970-1980)

Since 1980 integrating 'Annales de la Nutrition et de $\Gamma$ Alimentation'

Senior Editor Editorial Board

N. Zòllner, München L.G. Alcindor, Paris D.E.M. Lawson, Cambridge

Main Editors

G. Wolfram, Freising J. Marks, Cambridge C. Barth, Kiel I. Macdonald, London 1

B. Brubacher, Basel J. Marks, Cambridge

J.W.T. Dickerson, Guildford C.F. Mills, Aberdeen

F. Falkner, Berkeley, Calif. D.J. Naismith, London Associate Editor Ch. Frayssinet, Villejuif K.R. Norum, Oslo

G. Debry, Nancy P. Fürst, Stuttgart/Hohenheim G. Schlierf, Heidelberg

L. Gueguen, Jouy-en-Josas M.A. Spadoni, Roma ;

L,. Hambraeus, Uppsala A.J. Vergroesen, Mariapfarr !

K. Hellström, Stockholm W. Waldhäusl, Wien!

F.A. Hommes, Augusta, Ga. A. Wretlind, Stockholm

B. Jacotot, Créteil Advisory Board, FENS H. Zucker, München 1

Austria Netherlands

B.M. Brandstetter, Wien R.J.J. Hermus, Boven-Leeuwen ‘

Bulgaria Norway

L. Balabanski, Sofia K.R. Norum, Oslo

Denmark Poland

E. Aaes-Jørgensen, København S. Berger, Warzawa

East Germany Spain

H. Schmandke, G. Varela, Madrid 
Bergholz-Rehbriicke Sweden

Finland L· Hambraeus, Uppsala

H. Koskinen, Helsinki Switzerland

Great Britain E. Jéquier, Lausanne

J. Dickerson, Guildford West Germany

Greece

A. Trichopoulou, Athens Italy

E. Lanzola, Pavia G. Schlierf, Heidelberg

Contents Vol. 33,1989

No. 1 Original Paper

Effects of an Intravenous Application of c//-Alpha-Tocopheryl Acetate on Tocopherol Status in

Man

Elmadfa, I.; Schwalbe, P.; Weidler, B.; Schlotzer, E 1

Effect of Varying Levels of Magnesium during Gestation and Lactation on Humoral

Immune Response and Tissue Minerals in Rats

Kubena, K.S.; Cohill, D.T.; McMurray, D.N 7

Some Effects of Various Dietary Carbohydrates on Thyroid Activity in the Rat

Macdonald, 115

Effects of Durum Wheat Dietary Selenium on Glutathione Peroxidase Activity and Se

Content in Long-Term-Fed Rats

Ciappellano, S.; Testolin, G.; Porrini, M 22

Glucose Turnover Rate and Perpheral Insulin Sensitivity in Alcoholic Patients without

Liver Damage

Bunout, D.; Petermann, M.; Bravo, M.; Kelly, M.; Hirsch, S.; Ugarte, G.; Iturriaga, H. 31

Adaptive Response of Rats with Diet-Induced Adiposity to Energy Restriction

Panemangalore, M.; Lee, C.J.; Wilson, K 39

Nitrosamine Metabolism in Protein-Deficient Weanling Rats during the Process of Repletion

Maduagwu, E.N $\quad 49$

Experimental Selenium Toxicity in Guinea Pigs: Biochemical Studies

Das, P.M.; Sadana, J.R.; Gupta, R.K.P.; Kumar, K 57

Announcements 64

No. 2 Review

Stable Isotopes as Tracers in Clinical Research

Pacy, P.J.; Cheng, K.N.; Thompson, G.N.; Halliday, D 65

Original Paper

Interrelationships between Body Weight, Body Fat Distribution and Insulin in Obese

Women before and after Hypocaloric Feeding and Weight Loss

Casimirri, F.; Pasquali, R.; Cesari, M.P.; Melchionda, N.; Barbara, L 79

Insulin-Like Growth Factor-I in the Parenterally Fed Low Birth Weight Infant

Saini, J.R.; Morgan, J.B.; Teale, J.D.; Kovar, I.Z 88

Interaction between Caffeine Intake and Nutritional Status on Growing Brains in Newborn

Rats

Nakamoto, T.; Hartman, A.D.; Joseph, F., Jr 92

Effects of Acarbose on Serum Lipoproteins in Healthy Individuals during Prolonged

Administration of a Fiber-Free Formula Diet 
Walter-Sack, I.E.; Wolfram, G.; Zöllner, N 100

Dietary-Induced Changes in Lipid and Fatty Acid Composition Can Modify Chronaxie Values in the Rat Sciatic Nerve

Tarozzi, G.; Barzanti, V.; Maranesi, M.; Turchetto, E 108

Varianz und zirkadianer Rhythmus des energetischen Erhaltungsbedarfs Erwachsener

Müller, H.L.; Kirchgessner, M.; Wolfram, G 114

No. 3 Original Paper

Changes in Phospholipid Fatty Acid Composition of Mouse Cardiac Organelles after Feed

ing Graded Amounts of Docosahexaenoate in Presence of High Levels of Linoleate.

Effect on Cardiac ATPase Activities

Croset, M.; Kinsella, J.E 125

Contents III

Effects of Dietary Polyamine Precursors on the Metabolism and Tissue Concentrations of Amino Acids in the Rat

Smith, T.K.; Lindqvist, L.; Alakuijala, L.; Eloranta, T.0 143

Effect of Dietary Vitamin E on the Toxicity of Autoxidized Oil to Rats

Yoshida, H.; Kajimoto, G 153

Effect of Dietary Lysine Level and Protein Restriction on the Lipids and Carnitine Levels

in the Liver of Pregnant Rats

Ortega, M.F 162

Dietary Cholesterol and Fats at a Young Age: Do They Influence Cholesterol Metabolism in Adult Life?

Temmerman, A.M.; Vonk, R.J.; Niezen-Koning, K.; Berger, R.; Fernandes, J 170

Circulating Thyroid Hormone Levels in Young Pregnant Rats and Their Fetuses: Effect of Malnutrition

Rostom de Mello, M.A.; Oliveira-Fiho, R.M.; Cury, L.; Souza Valle, L.B 181

Announcement 188

No. 4 2nd European Symposium on Purine and Pyrimidine Metabolism in Man

Gut Ising/Chiemsee, September 5-8, 1989

Abstracts

Guest Editors: U. Gresser, München, W. Löffler, München, N. Zöllner, München

No. 5 Original Paper

Lack of Effect of Purified Cellulose and Hemicellulose on the Digestion and the Intestinal Absorption of Dietary Lipids in the Rat

Borel, P.; Lairon, D.; Senft, M.; Garzino, P.; Lafont, H 237

Urinary Oestrogen Excretion after the Menopause in Relation to Age and Body Mass

Mole, P.A.; Rae, M.H.; Paterson, C.R 246

Modulation of Albumin Secretion by Ornithine Alpha-Ketoglutarate in Adult Rat Hepato-

cyte Cultures and a Human Hepatoma Cell Line (HepG2)

Lescoat, G.; Desvergne, B.; Loreal, O.; Pasdeloup, N.; Deugnier, Y.; Bourel, M.; Brissot, P. 252

Effect of Vitamin D Administration during Pregnancy on Neonatal Growth in the Rat

Marya, R.K.; Lai, H.; Chugh, K.; Saini, A.S 261

Effect of Pre- and Postnatal Protein Undernutrition on Glycemia, Ketonemia and Liver

Glycogen Concentration in Suckling Rats

Gamallo, J.L.G.T.; Perry, M.L.S.; Trindade, V.M.T.; Pereira, I.R.G.; Bernard, E.A. . 266 In vivo 14C Isotopic Evaluation of Amino Acid Oxidative Catabolism in the Growing 
Chick. I. Fast Respiratory 14C 02 and Acetyl-CoA Renewal

Simonnet, F.; Ng, L.T.; Auliac, P.; Jacob, A.; Pascaud, M 271

In vivo 14C Isotopic Evaluation of Amino Acid Oxidative Catabolism in the Growing

Chick. II. Slow Respiratory $14 \mathrm{C} \theta 2$ and Protein Renewal

Simonnet, F.; Ng, L.T.; Auliac, P.; Jacob, A.; Pascaud, M 279

Effects of Diet and Metoprolol on Lipid Levels in the Blood Plasma and Morphology of the

Heart and Intramural Branches of Coronary Arteries of Spontaneously Hypertensive

Male Rats. A 9-Month Study

Sjöblom, L.; Eklund, A.; Östlund-Lindqvist, A.-M.; Jönsson, L 284

Effects of Stigmasterol-Supplemented Diets on Fecal Neutral Sterols and Bile Acid Excretion in

Rats

Andriamiarina, R.; Laraki, L.; Pelletier, X.; Debry, G

Announcement 304

IV

Contents

No. 6 Original Paper

Bromocriptine Alters Hormone Rhythms and Lipid Metabolism in Swine

Cincotta, A.H.; Meier, A.H.; Southern, L.L 305

Adipose Tissue Levels of Fatty Acids and Tocopherol in Young and Old Women

Schäfer, L.; Overvad, K.; Thorling, E.B.; Velander, G 315

Effect of 5\% Galactose Diet on Galactose and Dulcitol in Plasma and Lens of Male and

Female Pigs

Alloussi, S.; Birlouez-Aragon, L; Fevrier, C; Papadopoulos, H 323

Direct Inhibitory Effect of High Glucose in Mesenteric Artery on Glucose Absorption from Isolated Perfused Rat Intestine

Mokuda, O.; Sakamoto, Y.; Ikeda, T.; Mashiba, H 330

Plasma Glucose and Insulin, Urinary Catecholamine and Cortisol Responses to Test Break fasts with High or Low Fibre Content: The Importance of the Previous Diet

Sundell, LB.; Hallmans, G.; Nilsson, T.K.; Nygren, C 333

Affinity Chromatographic Identification of Vitamin B П-Binding Proteins in Egg White

Zak, Z.; R³/4pala, M.; Turyna, I.; Wenhrynowicz, O.; Kozik, A 341

Experimental Selenium Toxicity in Guinea Pigs: Haematological Studies

Das, P.M.; Sadana, J.R.; Gupta, R.K.P.; Gupta, R.P 347

Insulin Extraction and Glucose Output by the Perfused Liver of Starved Rats

Ikeda, T.; Fujiyama, K.; Hoshino, T.; Takeuchi, T.; Mashiba, H.; Tominaga, M. . . 354

Effects of Fish Oil Capsules in Two Dosages on Blood Pressure, Platelet Functions,

Haemorheological and Clinical Chemistry Parameters in Apparently Healthy Subjects

Bach, R.; Schmidt, U.; Jung, F.; Kiesewetter, H.; Hennen, B.; Wenzel, E.; Schieffer, H.;

Bette, L.; Heyden, S 359

Announcement 368

Author Index 369

Subject Index 371

S. Karger Medical and Scientific Publishers

Basel · München · Paris · London · New York · New Delhi · Bangkok — Singapore · Tokyo ·

Sydney

Drug Dosage 
The authors and the publisher have exerted every effort to ensure that drug selection and dosage set forth in this text are in accord with current recommendations and practice at the time of publication. However, in view of ongoing research, changes in government regulations, and the constant flow of information relating to drug therapy and drug reactions, the reader is urged to check the package insert for each drug for any change in indications and dosage and for added warnings and precautions. This is particularly important when the recommended agent is a new and/or infrequently employed drug.

All rights reserved.

No part of this publication may be translated into other languages, reproduced or utilized in any form or by any means, electronic or mechanical, including photocopying, recording, microcopying, or by any information storage and retrieval system, without permission in writing from the publisher or, in the case of photocopying, direct payment of a specified fee to the Copyright Clearance Center (see 'Information for Readers and Subscribers').

(C) Copyright 1989 by

S. Karger AG, P.O. Box, CH-4009 Basel (Switzerland) Printed in Switzerland by Thür AG Offsetdruck, Pratteln 